am anxious to state it, in order to clear myself of any suspicion of having borrowed from that distinguished writer without acknowledgment.

W. OGLE

April 2

\section{Rime Cloud observed in a Balloon}

IN his letter, inserted in NATURE, vol, xxv. p. 507, Dr. Hermann Kopp says that "when Kratzenstein (1744) advocated the opinion anticipated by Halley (1686), that water-vapour may be condensed in a vesicular state, he availed himself of the observation that in clouds and mists and condensed steam over boiling water, a rainbow is not to be observed in reflected light." I have good grounds to suppose these negative observations were made only because the intensity of reflected light was not sufficient, as a white rafnbow is produced under these circumstances. In support of these assumptions, I may be allowed to quote an observation published by M. Faye in vol. xxviii. of the Comptes rendus, 1849 , p. 244 , where the celebrated astronomer says :-

"J'ai observé cette nuit un phénomène que je signale aux personnes qui l'occupent d'optique méteorologique. En sortant d'une salle de travail qui donne sur le parc de l'observatoire, j'ai remarqué que la lumiere d'un bec de gaz en arrière produisait en face de moi par la porte entrouverte un arc-en-ciel blanc semblable à un halo lunaire . . . Cet arc-en-ciel blanc doit être aisement réproduit par les temps de brouillards; ou pourrait le faire naître a la lumière électrique . . . et l'étudier plus complétement que je ne l'ai fait."

It is to be regretted that the suggestion of the illustrious astronomer has not been taken into account by the physicists in an age when the electric light is so frequently in their hands. I believe that this kind of experimentation will elucidate the controversy, and afford some new ideas on the constitution of clouds under several circumstances, as artificial clonds may be produced by uring jets of steam or condensing steam over a boiler. I believe a white rainbow, which is really the corona of the aeronauts, would appear under these circumstances, and the phenomenon would take another aspect when electric light falls on solid snow. The electric lighthouses now building will afford to the keepers many opportunities of making this observation. I take advantage of this opportunity to ask $M$. Hermann Kopp if he will obligingly suggest some observations to be made in a balloon for examining whether the minute particles of water are liquid or solid. By doing so, he will confer a great benefit on aëronauts next winter.

W. DE I'ONVIELLE

\section{The Kunnungs}

HAving just returned from an exploring expedition east of Asam, where I met a number of "Kunnungs," I may report that they appear distinct, both in language and physique, to the Naga groups south of Asam, and, in language, have affinities with Singphos. Those I saw, were with one exception, much more prepossessing in appearance than the other hill-savages, and in colour very pale, i.e. 33 and 45 of Broca's scale. I have got a limited vocabulary. They are great iron and steel workers, and extend from the Mli-kha to what they call the boundary of China, living on pile platform dwellings, raiding like all the bill-men about, having "morongs," or separate houses for the unmarried ; like others, also, their "morals" (as we should say) begin with marriage.

I am now preparing some notes of my trip, and send this as I am writing, as it may interest some to know whom these people seem like.

Subsagar, Asam

S. E. PEAL

\section{Burrowing Larvæ}

IN his letter ante p. 265 , Dr. Hagen states that he had "been informed by $M$. Lesquereux that a large number of magnolia leaves, from the Tertiary of Alaska, show serpentine trails not larger than a thread, running all over the leaves, apparently under the epithelium," and Dr. Hagen evidently believes them to be the mines or burrows of some Tineid larva. Precisely such mines are now made in this country, in the leaves of magnolias, by a larva of the genus Phyllocnistis, Zell. The moth has not been bred from the larva, but the mine and larva are indistinguishable from those made by Phyllocnistis liriodendronella, Clem., in leaves of Liriodeno'ron tulipifera, and doubtless it is the same species in both of these allied trees. "What is a species?" however, is a doubtful question in Phyllocnistis, at least in our American species. No species of this or any other genus is known to burrow in the leaves of any of the other genera of plants named in Dr. Hagen's letter besides Magnolia, Liquidambar, and Sassifras. Another Phyllocnistis mines the leaves of Liquidambar, and has been described by me under the name of $P$. liquidambar-isella, but it is probably identical with $P$. vitifoliella, Cham. The mine is similar to, but distinct from, that of $P$. liricdendronella. The larva which mines Sassafras leaves is that of Gracilaria sassafracella, Cham., but it leaves the mine at a very early stage of larval life, when the mine is too small to be recognised in a fossil leaf, unless it has been unusually well preserved. In this connection I will add that 1 distinctly remember having somewhere seen a figure, by Lesquereux I think, of a fossil leaf of a species of Acer, on which there were several blotches, one of which bore a strong resemblance to the mine of Lithocolletis aceriella, now made in leaves of Acer saccharinum; but as I saw only the figure, and not the fossil, I cannot be certain that it was a mine of that larva.

Covington, Ky., U.S.A., March 10 V. T. Chambers

\section{Vignettes from Nature}

W.ILL Dr. W. B. Carpenter kindly tell us where in "South America" are the "coprolite diggings" from which he had "just seen a collection of sharks' teeth"? I am aware that at Bull River, South Carolina, North America, are vast deposits of "coprolites" (almost identical in character with those of our Suffolk Cray), which are largely imported into England from the United States. Of these Bull River sharks' teeth, \&c., I have had many specimens.

Ipswich, March 23

\section{Red Flints in the Chalk}

AT one part of Caterham Valley, Surrey, there is an example of an abundance of red flints similar to that mentioned by W. Fream (NATURE, vol. xxv. p. 437). The colour is, doubtless, due to the presence of oxide of iron, but I have not tested it. I find that the red flints invariably contain the remains of sponges, the network of spiculae of wbich, reing coated with the oxide of iron, show up in crimson or orange on a ground of black flint, and are very beautiful objects under a lens. Thus it appears to me that the redness observable in these flints is mostly due to the inclosure of sponges which contam either oxide of iron or iron which afterwards tecame oxidised. The yellow oxide of iron is disseminated throughout the chalk itself, some strata being very much stained by it. JOHN BADCOCK, Jun.

270, Victoria Park Road, E.

\section{ON THE DISPERSAL OF FRESHWATER BIVALVES}

THE wide distribution of the same species, and of closely-allied species of freshwater shells must have surprised every one who has attended to this subject. A naturalist, when he collects for the first time freshwater animals in a distant region, is astonished at their general similarity to those of his native European home, in comparison with the surrounding terrestrial animals and plants. Hence I was led to publish in NATURE (vol, xviii. p. I2O) a letter to me from Mr. A. H. Gray, of Danversport, Massachusetts, in which he gives a drawing of a living shell of Unio complanatus, attached to the tip of the middle toe of a duck (Querquedula discors) shot on the wing. The toe had been pinched so bard by the shell that it was indented and abraded. If the bird had not been killed, it would have alighted on some pool, and the Unio would no doubt sooner or later have relaxed its hold and dropped off. It is not likely that such cases should often be observed, for a bird when shot would generally fall on the ground so heavily that an attached shell would be shaken off and overlooked.

I am now able to add, through the kindness of Mr. W. D. Crick, of Northampton, another and different case On February i 8 of the present year, he caught a female Dytiscus marginalis, with a shell of Cyclas cornea clinging to the tarsus of its middle leg. The shell was 45 of an inch from end to end, 3 in depth, and weighed (as.Mr. Crick informs me) 39 grams, or 6 grains. The valves 